\title{
A Comparative Analysis of the Performance of Selected Rural Banks in Enchancing Agricultural Development in Benue State, Nigeria: 2010-2012.
}

\author{
Ali Ocholi ${ }^{1}$ and M.Y Amodu ${ }^{2}$ \\ Department of Agribusiness, College of Management Sciences, University of Agriculture, Makurdi, Nigeria. \\ Department of Agricultural Economics and Rural Sociology, Faculty of Agriculture, Ahmadu Bello University \\ Zaria Nigeria.
}

\begin{abstract}
The study compared the performances of Deposit Money Bank, Bank of Agriculture and Microfinance Banks in the rural communities of Benue State Nigeria: 2010 - 2012. Data were collected from 180 respondents using multistage sampling technique. Structured questionnaire was administered on randomly selected respondents who were beneficiaries of agricultural credits from these banks. The data were analyzed using descriptive statistics. The results obtained revealed a significant level of outreach in terms of savings deposit mobilized and loan disbursed. Comparatively, the Deposit Money Bank was most successful in terms of savings

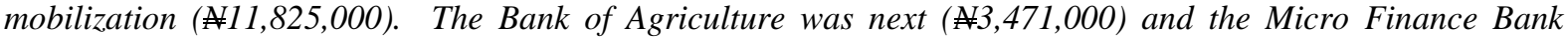
(\$429,000). With respect to funding rural agriculture, Deposit Money Bank was highest $(54.24 \%)$ followed by Bank of Agriculture (45.18\%) and the least was Micro Finance Bank (0.58\%). The study recommended that increased financial resources should be made available by the State and Donor Agencies to the Rural Banking Institutions to reactivate them especially during their negative cash flow stages. The Rural Banking Institutions should also embark on aggressive mobilization of savings and recovering of their loans to enable them become self-sustainable.
\end{abstract}

Keywords: Agricultural Development, Benue State, Nigeria, Rural Banking Institutions, Small Scale Farmers.

\section{Introduction}

The primary concerns of nations all over the world have been to attain accelerated and self-sustaining economic growth. While developed countries concern themselves more with sustaining economic growth, that of developing countries have been to project themselves on the path of economic growth. Whatever stages of development a country is, there is no doubt that banks play important roles in the process of growth and eventual economic development. The banking industry around the world has witnessed remarkable changes in recent decades, given the increasing wave of globalization, structural and technological changes and integration of financial markets. As Mckinnon (1973). [1] observed in their seminar work on the key roles of banks as propellants of growth and development in developing economies, a feeble banking system is repressive, distortionary and disconnects the intermediation process thereby precipitating macro-economic instability. This requires that policy makers, as Nnanna (2001). [2] opines, must articulate robust policies that will deepen the financial system to enable banks play their roles most efficiently. In Nigeria, the ability of the banking industry to play its role has been periodically punctuated by its vulnerability to systemic distress and macro-economic volatility, making policy fine tuning inevitable. Nnanna (2005). [3] showed that historically, the Nigerian banking industry had evolved in four stages. The first stage can be best described as the unguided laisez faire phase (1930-59), during which several poorly capitalized and unsupervised indigenous banks failed in their infancy. The second stage was the control regime (1960-1985), during which the Central Bank of Nigeria ensured that only "fit and proper" persons were granted banking license subject to the prescribed minimum paid up capital. The third stage is the post Structural Adjustment Programme (SAP) or de-control regime (19862004) during which the neo-liberal philosophy of "free entry" was overstretched and banking licenses were dispensed by the political authorities on the basis of patronage. The emerging fourth stage is the era of consolidation 2004 to a foreseeable future with major emphasis on re-capitalization and proactive regulation based on risk or risk-focused supervision framework. For an under-developed economy like Nigeria, the use to which rural banks can be put are enormous. A lot of money is generated in the rural areas which can be put to significant use. Rural banks can garner these resources (which are quite substantial) together and distribute efficiently among the various productive sectors of the economy. The advantages of this to the economy are many. In the first instance, incomes are created for the rural communities. By cultivating the banking habit and keeping their money in banks they earn interest on them, instead of making them idle. This leads to increased earnings for them and a higher purchasing power which makes for better standard of living. On the other side of the coin are the borrowers who need large sums of money to finance desired projects. As long as they can borrow from the banks and repay the interest and capital, they keep the banks in business, thus keeping 
thousands of people in employment. If the villagers are encouraged to borrow, it is definite that they will invest funds in the rural areas to give impetus to their farming activities and cottage industries. By this action more food will be produced and a lot of jobs also created. In Nigeria, one of the most discussed issues in recent times is that of agricultural development. Agriculture has become more prominent because of dwindling revenue from the oil sector. Nigeria is now looking, inwards to see the possibility of tapping more revenue from the agricultural sector and becoming food sufficient. Agriculture plays fundamental role in the development of the economy of any nation. Experience has shown that no modern developed country around the world achieved rapid industrialization without having previously or simultaneously attained a marked increase in agricultural production (Edordu, 1986). [4] Despite the fact that the nation is blessed with abundant human and natural resources which are favourable for agricultural development, agriculture in Nigeria is dominated by small-scale farmers who are responsible for about 90 percent of the total production (Olatunbode, 1990) [5]. These farmers are characterized by low farm incomes and low technology input. There is an overwhelming agreement that whatever is the programme package, or technological innovation introduced to improve agriculture, its adoption and use will to a large extent be implicitly and explicitly dependent on the existence of desirable and necessary infrastructure that are essential for agricultural production and on the farmers' ability to finance such innovation (Olatunbode, 1990). [5] The farm business, like most other business ventures needs large (and sometimes lumpsum) amount of capital to start, and/or expand. Unfortunately, most farmers in Nigeria are never in the position to finance such investments out of their own personal saving. Thus "outside funding" is generally considered necessary in order to induce more capital investments in the agricultural sector of the economy (Barau, 1991). [6] It is clear from the foregoing that agricultural development is dependent on the availability of credit. In recognition of both the weak financial base of the majority of the Nigerian farmers and the paucity of rural financial services available in the rural areas. The Government in Nigeria over the years, have initiated publicly financed credit programmes targeted at the rural poor farmers. Prominent among these are the Bank of Agriculture which was called Nigerian Agricultural Co-operative and Rural Development Bank (NACRDB), the Supervised Agricultural Credit Guarantee Scheme, the Commercial Banks' Rural Banking Scheme, the Community Banks, now named and converted to Micro-Finance Banks. These financial institutions have an important role to play in credit delivery and savings mobilization particularly in the rural areas of the country, and in the development of the financial system as a whole. In recent years, the performance of most of these banking institutions in terms of outreach (coverage) and services has generally been disappointing. While some of these formal financial institutions may have performed relatively well, others have not made any impact to improve the conditions of the small-scale farmers who are their primary clientele. The need therefore to document the comparative performances of the selected rural banking institutions in Benue State Objectives of the Study

The broad objective of this study was to compare the performances of Deposit Money Bank, Bank of Agriculture and Micro Finance Banks in the rural communities of Benue State of Nigeria: 2010-2012. The specific objectives are to:-

(i) access the selected banks in terms of their savings deposit

(ii) evaluate the loan disbursements of the banks

(iii) examine the loan recovery of the selected banks

(iv) Identify the gender distributions of the loan beneficiaries of those banks.

\section{Literature Review}

Rural banking can be realized by either of two ways: (a) persuading, coercing or directing existing banks to open rural branches or (b) creating special banks that will establish their presence in the rural areas (Ojo and Adewunmi, 1982). [7] Thus a rural bank is that sited in a predominantly subsistence agricultural community for mobilizing and re-lending idle funds within the community so as to develop, modernize, and raise the living standards of the rural communities.

\subsection{Background to Rural Banking in Nigeria}

It is important to appreciate the existence of informal rural financial markets before the introduction of rural banking in Nigeria. These informal rural financial markets mobilize savings and advance credits to rural population at various charges. Such markets are often made up of different savers and lenders such as money lenders, thrift cooperatives and credit societies, Esusu group, merchants, relatives and friends (Odoemenem, 1992, Nkposong, 1999).[8] But the imperfection and inefficiency which characterized the services of these markets underscore the need for formal rural financial market such as rural banking. Government believes that if the market is left on its own, the flow of rural credit will be seriously jeopardized -hence the government's intervention in formal rural financial markets. Prior to 1975, the Central Bank of Nigeria adopted moral suasion by appealing to banks to open up branches in the rural areas to help particularly in agricultural development. This was not heeded hence a change of approach via section 4 of the Banking Decree of 1969 where banks were 
obliged to obtain prior approval of the CBN before they could open a new branch. Here banks were denied approval if their requests to open more branches in the urban areas were not matched by proposals to open branches in rural areas simultaneously with or in advance of the new urban branches (Olashore, 1979). [9] However, those banks reneged on their undertakings hence it became obvious that no amount of persuasion or subtle device would compel banks to establish in the rural areas. At the instance of the CBN, the financial system review Committee in 1975 recommended and the Federal government approved a programme of geographical dispersal of bank branches particularly designed to ensure the penetration of the rural areas by banks, that is, a conscious and deliberate effort to direct banks into rural areas. In a rural banking survey conducted by the CBN in 1977, it disclosed that there were no bank facilities, in the many communities whose population range was between 10,000 and 100,000 people. It was also discovered that after 84 years of banking in Nigeria, by 1977, only 470 bank branches existed with an abnormal ratio of bank per person standing at $1 / 170,000$.Thus, the 'Rural Banking Scheme' was inaugurated in July 1977 with the decision to allocate the identified rural centres to banks on the basis of a formula which related the number of each bank's rural branches to its total branch network throughout the country.

The Specific Objectives of the Rural Banking Scheme were:

(a) Mobilizing rural savings for the insurance of credit to the rural operators,

farmers and businessmen;

(b) Extending banking services and habits to rural areas;

(c) Encouraging increase in banking density of the country;

(d) Enhancing development of rural areas and hence stem the alarming tide of rural urban migration.

Due to the large number of rural communities in need of banking services, it was decided to phase the programme for ease of execution and control. The first phase of the programme spanned July 1977 to June 1980 ( 3 years) with 200 branches slated to be established by the 19 commercial banks in the rural areas. The second phase of the Rural Banking Programme lasting between 1980 and 1983 had 266 branches planned to be opened. The programmed entered the third phase in August 1983 and spanned till July, 1989 with 300 branches allocated for opening in the rural areas by the 28 commercial banks operating in the country by 1985 with the biggest three banks (First Bank of Nigeria, United Bank for Africa and Union Bank of Nigeria) being allocated 28 centres each while the very new banks got five centres each. The total number of branches opened for the three phases were 756 leaving ten outstanding. Because of their profit maximizing behavior, sophisticated operational mode and collateral requirements for credit delivery commercial banks are probably not the best institutions to provide credit facilities to the rural population. Therefore in October, 1989, Peoples' Bank of Nigeria (PBN) was established with similar objectives of the rural Banking scheme. The Peoples' Bank was set up to meet the credit needs of the rural and urban poor, artisans, farmers, petty traders and vehicle mechanics. However, because it is supply-led and heavily dependent on subventions from the Federal Government for its operation, and the fact that the recovery of loans was not very efficient, the bank was facing problems of decapitalization due to heavy overheads that outstrip earnings. It was against this background that Community Bank was conceived to answer some of the observed weaknesses in credit delivery to the grassroots. Community bank was therefore designed to fill the credit delivery gap created by Peoples' Bank and the conventional banks. However, unlike the Peoples' Bank, Community Bank is owned and managed by the community itself. This inculcates a sense of belonging and commitment to the success of such banking project. According to Anyanwu, et al, (1997). [10] Community Banks had been able to mobilize a total deposit of about N9.8 billion by the year 2000 and total micro-credit had risen to N4.3 billion for the same period. The ratio of total micro- credit to total deposit was thus 43.9 percent which was encouraging and capable of lifting the rural economy from her low rate of development. The Community banking system holds much promise for turning around the economy of Nigeria and making its development truly people-oriented, and a strong catalyst for democratization, if the government could allow the communities to plan and develop their local economies using their initiatives. For community Banks to be more relevant in the present circumstance, they have been converted to Microfinance Bank with a framework that is supposed to be adequately capitalized, appropriately regulated and supervised to address the need of financing at the micro levels of the economy.

\subsection{Measuring Performance of Rural Banking Institutions}

\section{Conceptual Framework}

Financial analysts in the past used low rates of delinquency and default as criteria for assessing the performance of financial institutions. The criteria are favoured based on the argument that low delinquency rate implies that lenders are careful in selecting borrowers and in recovering loans. Vogel (1981), [11] opined that, low rate of loan delinquency suggests that loans are allocated to productive activities. Financial ratios are another tools used in the assessment of financial institutions. This method of analysis had attracted much criticisms based on the fact that the tools do not take subsidy into account. This becomes a major lapse when 
Government owned financial institutions are being evaluated. Moreover, by the use of ratios, the extent to which the objective of a financial institution is achieved could not be ascertained. Ratios are mostly suitably used when assessing financial performance of profit maximizing organizations. This tool is not designed to measure the financial performance of financial status of Community or State owned development financial institutions which are not profit maximizers and which benefit from subsidies that carry opportunity cost to the society. Therefore, some adaptations of the ratios have been made to focus on the real financial cost of continued operations, particularly when subsidies to the RBIs concerned constitute common practice. A framework introduced by Yaron (1992), [12] for assessing the performance of rural financial intermediaries ensures the unearthing of all subsidies associated with RBI operation. The framework proposes two primary criteria: Outreach and self-sustainability index. Outreach is a general term for a hybrid index which takes into account the extent of market penetration and the quality of financial service provision. Self-sustainability measures the RBIs' subsidies received against the interest earned and is captured by the composite subsidy dependence index, (SDI) (Yaron, 1997).[13] This type of analysis takes into account the overall social cost of operating a RBI, including the full value of subsidies received by the institution. In particular, the SDI makes explicit the subsidy needed to keep the RBI afloat, much of which is not reflected in conventional accounting and unable to be captured by traditional financial ratio analysis (Yaron, 2000). [14] Some primary indicators of outreach performance are changes in the value of total savings deposits; the value of the outstanding loan portfolio; the number of branches or units established; the proportion of the target rural population served; the value and number of loans extended and the rates of participation by women (Gurgard et al. 1994 and Yaron, 1994). [15] These criteria provide quantifiable proxies for assessing the extent to which rural banking institutions have achieved their objectives and justify the social costs associated with supporting such institutions.

\subsection{The Study Area}

\section{Methodology}

The study was conducted in Benue State of Nigeria. Benue State derives its name from River Benue, the second largest river in Nigeria. The State created in 1976 is located in the Middle Belt of Nigeria. It is an area within the quadrilateral formed by Latitudes $4^{\circ}$ and $14^{0}$ North of the Equator and Longitudes $2.75^{\circ}$ and 14.5 ${ }^{0}$ East of the Greenwich Meridian. NPC (2006). [16] The State shares boundaries with five other States, namely: Nasarawa to the North, Taraba to the East, Cross River to the South-East. Part of the State also shares boundary with the Republic of Cameroon. The State is also bordered on the North by $280 \mathrm{Km}$ of River Benue, and is traversed by $202 \mathrm{Km}$ of River Katsina-Ala in the inland areas.

The State has a total area of about 30955 square kilometers and administratively it is divided into 23 Local Government Areas with its Headquarters at Makurdi. According to the 2006 Census results, Benue State has a population of about 4.2 million. NPC, (2006) [16] There are two main ethnic groups in Benue State, namely Tiv, who represent about 72 percent of the total population and the Idoma who constitute slightly over 21 percent of the population. The Igede tribe represents 6 percent of the population; smaller communities of Hausa, Fulani, Jukun, Abakwa Nyifon, Etulo and Igbo traders account for the remaining 1 percent of the population. About 75 percent of the population live in the rural areas and the main occupation is farming. Benue State has a tropical climate, which manifests two seasons. The rainy season is April to October while the dry season is from November to March. Annual average rainfall varies from $1750 \mathrm{~mm}$ on the Southern part of the State to $1250 \mathrm{~mm}$ in the North. In the mountain regions Turan and Ikyurav-ya areas of Kwande Local Government, average rainfall rises up to $4000 \mathrm{~mm}$. The hot season comes in mid-April with temperature between $32^{\circ}$ and $38^{\circ} \mathrm{C}$ with high humidity. BNARDA (1999). [17] The State stretches across the transition belt between the forest and savanna vegetation. Much of the area consists of undulating hills or grassy open space on the North and derived savanna in the South. Benue State is referred to as the "Food Basket of the Nation" because of the abundance of its agricultural resources. About 80 percent of the State population is estimated to be involved directly in subsistence agriculture. The State is a major producer of food and cash crops like yam, cassava, rice, groundnuts and maize. Others include sweet potatoes, millet, sorghum, sesame and a wide range of others like soyabeans, sugar cane, oil palm, mango, citrus and banana. Irrigation farming along the bank of Rivers Benue and Katsina-Ala is a common feature. The State can boast of a great deal of livestock resources like goats, though the major occupation is crop farming, a lot of fishing activities on Rivers Benue and Katsinaala are carried out; irrigation is widely practiced along the reverine areas during the dry season; growing vegetable crops such a tomatoes, okro, carrot, onion, pepper and amaratus in large quantities. It is also common practice to find each farming family keeping one form of livestock or the other such as poultry, rabitry, piggery, sheep and goat on a small scale. Poultry, sheep, pigs and cattle are traditionally reared on free range by small holder farmers. The strategic location of Benue State between the Southern forest regions and in the Northern semi and grassland regions of the country makes it to have fertile land for agriculture with the estimated arable land constituting about 60 percent of the total area. Average farm size is 1.5 to2.0 hectares BNARDA (1999). 
[17] There are many Commercial, Development, and Microfinance Banks in the State. These banks have rural branches all over the States. There is a branch of CBN in the State Capital, Makurdi. Benue State is delineated into three agricultural zones namely zones A, B and C.

\subsection{Sampling Technique and Sample Size}

The Population of this study encompassed all the rural farmers who obtained loans from the banks in the communities under study in Benue State. (appendix 1). Multistage selection involving simple random sampling techniques were adopted. First, all the three agricultural zones A, B and C were purposively selected based on the high concentration of loan beneficiaries in the zones. The second stage involves purposive selection of three (3) Local Government Areas from each of the zones namely: Ukum, Katsina-Ala and Vandeikya in zone A, Gboko, Gwer and Makurdi in zone B, and Otukpo, Okpokwu and Oju in zone C. In stage three, two communities in each of the Local Government Areas were randomly selected. Having drawn the sampling frame of agricultural loan beneficiaries in these communities, $10 \%$ of the agricultural loan beneficiaries were randomly selected. Thus, a total of 180 agricultural loan beneficiaries were selected from 1804 agricultural loan beneficiaries for the study. Secondly, the list of all banks, Deposit Money banks, Bank of Agriculture and Microfinance banks were obtained from the Central Bank of Nigeria, Makurdi Branch. Selection of the banks was done using the stratified sampling method.

The banks were stratified into:

(a) Deposit Money banks (United Bank for Africa or Union Bank of Nigeria);

(b) Micro-finance banks;

(c) Bank of Agriculture.

A simple random sampling was carried out to draw from each stratum where there are more than two bank branches in the category from the selected agricultural development zones. Six bank branches of the three categories of banks were selected per each agricultural development zone. This translates into eighteen bank branches for the three agricultural zones. The list of all the small-scale agricultural loan beneficiaries from 2010-2012 were obtained from these bank categories in each of the agricultural development zones from the agricultural credit officer or bank officials. This served as sampling frames from which 180 farmers (borrowers) were randomly selected. This represented 10 small scale farmers borrowers per bank branch. Purposively, the officials of these bank categories in each agricultural development zone were selected for questionnaire administration. The officials of the bank include: Managers, Officers and Clerks.

\subsection{Method of Data Collection}

Data were collected from primary and secondary sources. Cross sectional socio-economic primary information were collected from selected farmer borrowers in Benue State. Information that were gathered include: the farmers characteristics such as age, years of farming experience, number and age distribution of household members, highest level of educational attainment, farm size, type and animal species produced, source of loan, amount of loan secured, period of securing the loan, amount paid, amount unpaid (yet to be paid), labour use level, fertilizer use level, level of agro-chemical used, farm income, off-farm income, primary occupation, detailed cost of production, revenue parameters and problems in sourcing for credit. Secondly, secondary data in components of the lending of the institutional credit sources from 2010 to 2012 were collected. These include: lending interest rate, grace period, frequency of supervision, amount lent per borrower, recovery rate, loan duration, moratorium period, value of total savings, market rate of interest, interest rate on concessional funds, average annual equity, annual profit before tax and problems encountered in agricultural loan administration. The primary data were collected with two sets of questionnaire. The first set of questionnaire was administered on the rural farmer-borrowers and the second set of questionnaire was administered on the rural banking institutions. Secondary data were collected from published and unpublished literature such as bank bulletins.

\subsection{Method of Data Analysis}

Descriptive statistics such as percentages as well as outreach performance index were used for data analysis. Outreach is a general term for a hybrid index which takes into account the extent of market penetration and quality of financial service provisions. It is measurable in terms of the number and gender dimension of farmers reached, total savings mobilized, volume of funds disbursed as loan to farmers and amount of loan repaid.

\section{Results And Discussion}

5.1 Determination of the Outreach Performance of Rural Banking Institutions in Benue State Nigeria 5.1.1 Savings Mobilization of RBIs in Benue State 2010 -2012

Table 1 displays the volume of savings mobilized from the rural communities of Benue State by the RBIs. It indicates that all the RBIs except the micro finance banks had impressive measure of outreach in terms 
of the volume of savings mobilization. Comparatively, the result shows that the Deposit Money Banks were clearly the most successful, posting about N11.83 billion or $75.20 \%$ of the grand total savings deposits mobilized from the rural communities of Benue State. The Deposit Money Banks was followed by the Bank of Agriculture which mobilized a total sum of N3.5 billion or $22.10 \%$ and the Microfinance banks which mobilized N429.5 million or $2.73 \%$ of the total savings deposits in rural communities in Benue State.

The implication of this result is that the inhabitants of rural areas in Benue State repose higher confidence in Deposit Money Banks than all other category of banks under study. This could be as a result of the bitter experience of the rural people with some distressed community banks in the rural areas. It could also be inferred that the preference of the deposit money banks by the depositors to other banks categories could be due to the attractive savings options obtainable in the Deposit Money Banks than in all other banks. Higher deposit interest is one of the savings option.

The performance of the Micro finance banks in mobilizing $2.7 \%$ of the total savings deposits in the rural areas is not impressive. Micro finance banks are supposed to be the people's bank and expected to have more patronage since it is their own bank.

Table 1: Volume of Savings Mobilized by Rural Banking Institutions in Benue State: 2010-2012

\begin{tabular}{|l|c|c|c|}
\hline \multicolumn{4}{|c|}{ Rural Banking Institutions } \\
\hline Year & $\begin{array}{c}\text { Deposit Money } \\
\text { Banks } \\
\text { (N'000,000) }\end{array}$ & $\begin{array}{c}\text { Bank of } \\
\text { Agriculture } \\
\text { (N'000,000) }\end{array}$ & $\begin{array}{c}\text { Microfinance Bank } \\
\text { (N'000,000) }\end{array}$ \\
\hline 2010 & 2925 & 867 & 138.2 \\
2011 & 3615 & 968 & 121.5 \\
2012 & 5285 & 1636 & 169.8 \\
\hline Grand Total & 11825 & 3471 & 429.5 \\
\hline Percentage & $75.20 \%$ & $22.10 \%$ & $2.7 \%$ \\
\hline
\end{tabular}

Source: Field Survey, 2012

The Bank of Agriculture mobilized 22.10\% savings deposit from the rural communities of Benue State (Table 1). This is impressive because this bank category has been conceived and packaged as a mere credit disbursing window. Its focus is to deliver credit rather than to meet the demand for deposits and savings services. With the deposit mobilized, the bank will be able to increase the supply of loanable funds.

\subsubsection{Agricultural loans made available to Small Scale farmers in Benue State}

Table 2 shows that the highest amount of credit (N975.9 million) or 54\% of the total fund extended to small-scale farmers in Benue State from 2010-2012 came from Deposit Money Bank. The second in the hierarchy of the credit status is Bank of Agriculture which extended N813 million or $45 \%$ of the total funds to the small scale farmers in rural communities of Benue State. Next on this scale was the Microfinance banks which extended a total of $\$ 10.4$ million or $0.5 \%$ of the total agricultural loans to the rural communities. It is therefore implied that the Deposit Money Bank has remained a hallmark in the supply of credit over the past years in the State. The essence is to promote rural development through boosting agricultural production, increasing rural incomes, and achieving greater equity.

Table 2: Amount of Agricultural Loans Made Available to Small-Scale Farmers by RBIs 2010-2012

\begin{tabular}{|c|c|c|c|}
\hline \multicolumn{5}{|c|}{ Rural Banking Institutions } \\
\hline Year & $\begin{array}{c}\text { Deposit Money Banks } \\
\text { (N'000,000) }\end{array}$ & $\begin{array}{c}\text { Bank of Agriculture } \\
\text { (N'000,000) }\end{array}$ & $\begin{array}{c}\text { Microfinance Bank } \\
\text { (N'000,000) }\end{array}$ \\
\hline 2010 & 341.19 & 63 & - \\
2011 & 434.42 & 668 & 2.58 \\
2012 & 200.25 & 82 & 7.82 \\
\hline Grand Total & $\mathbf{9 7 5 . 8 6}$ & $\mathbf{8 1 3}$ & $\mathbf{1 0 . 3 6 3}$ \\
\hline
\end{tabular}

Source: Field Survey, 2012

\subsubsection{Share of Loan Disbursement to Savings Mobilization}

The result in Table 3 shows that the Bank of Agriculture made the highest loan commitment to agriculture, representing $23.42 \%$ of its total savings mobilized in the State. This was followed by the deposit money banks which made a credit commitment of $8.25 \%$ of total savings mobilization to agriculture. Though in naira or numerical term, the deposit money banks made the highest (N975.9 Million) loan commitment to agriculture of all the banks under study, the credit disbursement to agriculture as percentage of its total savings mobilization was very low (8.25\%), trailing behind the Bank of Agriculture. 
Table 3: RBIs Loan Disbursement as a Percentage of Total Savings mobilization: $2010-2012$

\begin{tabular}{|l|c|c|c|}
\hline \multicolumn{1}{|c|}{ Indicators } & $\begin{array}{c}\text { Deposit Money } \\
\text { Banks } \\
\text { (N'000,000) }\end{array}$ & $\begin{array}{c}\text { Bank of } \\
\text { Agriculture } \\
\text { (N'000,000) }\end{array}$ & $\begin{array}{c}\text { Microfinance } \\
\text { Bank } \\
\text { (N'000,000) }\end{array}$ \\
\hline Amount of Savings Mobilized & 11,825 & 3,471 & 429.5 \\
\hline Amount of loan Disbursed to Agriculture & 975.86 & 813 & 10.363 \\
\hline $\begin{array}{l}\text { Loan Disbursement as \% of Savings } \\
\text { Mobilized }\end{array}$ & $8.25 \%$ & $23.42 \%$ & $2.41 \%$ \\
\hline
\end{tabular}

Source: Field Survey, 2012

The implication of this result is that generally the deposit money banks and Microfinance banks agricultural loan commitment as percentage of their total savings mobilization is abysmally and basically low. This is a confirmation of the neglect and reluctance of these banks in supporting agriculture. They are usually overwhelmed by some commercial considerations like trading; contracting to mention but a few whose pay back period is short. This selective and preferential lending policy are re-enforced by the high level of risks and uncertainties involved in lending to rain fed agriculture. Therefore, the use of people-oriented commercial banks as a strategy for channeling funds to the agriculture sector should be reviewed.

\subsubsection{Loan Recovery Rates of RBIs}

Table 4 shows marked variation in short and medium term loan recovering rates of the RBIs under study. The result indicates that during the period under review, the Deposit Money banks posted the least $(25.51 \%)$ mean annual loan recovery rate.

Table 4: Loan Recovery rates of RBIs in Benue State 2010-2012

\begin{tabular}{|c|c|c|c|c|c|c|c|c|c|}
\hline Year & \multicolumn{3}{|c|}{ Deposit Money Bank } & \multicolumn{3}{c|}{ Bank of Agriculture } & \multicolumn{3}{c|}{ Microfinance Bank } \\
\hline & $\begin{array}{c}\text { Amount } \\
\text { Lent Out } \\
\text { (N'000,000) }\end{array}$ & $\begin{array}{c}\text { Amt. } \\
\text { Repaid } \\
\left(\mathrm{N}^{\prime} 000,000\right)\end{array}$ & $\begin{array}{c}\text { Repayment } \\
(\%)\end{array}$ & $\begin{array}{c}\text { Amount } \\
\text { Lent Out } \\
\text { (N'000,000) }\end{array}$ & $\begin{array}{c}\text { Amt. } \\
\text { Repaid } \\
\left(\mathrm{N}^{\prime} 000,000\right)\end{array}$ & $\begin{array}{c}\text { Repayment } \\
(\%)\end{array}$ & $\begin{array}{c}\text { Amount } \\
\text { Lent Out } \\
\left(\mathrm{N}^{\prime} 000,000\right)\end{array}$ & $\begin{array}{c}\text { Amt. } \\
\text { Repaid } \\
\left(\mathrm{N}^{\prime} 000,000\right)\end{array}$ & $\begin{array}{c}\text { Repayment } \\
(\%)\end{array}$ \\
\hline 2010 & 116 & 37 & 32.90 & 99 & 75 & 75.6 & 2.50 & 1.25 & 50 \\
\hline 2011 & 368 & 29.6 & 8 & 199 & 176 & $88 \%$ & 3.00 & 1.8 & 60 \\
\hline 2012 & 492 & 175.4 & 35.65 & 371 & 170 & 45 & 4.86 & 3.16 & 65 \\
\hline Total & 976 & 242 & 24.80 & 669 & 421 & 62.93 & 10.36 & 6.21 & 59.94 \\
\hline X & 325 & 80.67 & 25.51 & 223 & 140.3 & 69.33 & 3.45 & 2.07 & 58.3 \\
\hline
\end{tabular}

Source: Field Survey 2012

The Bank of Agriculture posted the highest (69.33\%) loan recovery rate. This is followed by Microfinance banks which posted the second highest loan recovery rate of $58.30 \%$.

The implication of this result is that the Bank of Agriculture and Microfinance Banks performed better than the Deposit Money Banks in agricultural loan recovery. The reason for this performance is informed by these banks promoting strict financial discipline among their borrowers than the Deposit Money bank. The banks are more likely to be involved in loan monitoring and supervision than the Deposit Money Banks. Furthermore, the reason for the success of these banks (Bank of Agriculture and Microfinance banks) performing better than the Deposit Money Banks in loan recovery is informed by the use of social or pressure group. This is perhaps the principal achievement that distinguishes them from other lending agencies. The unimpressive performance of the Deposit Money Banks in loan recovery rate (25.51\%) could be attributed to the heavy work load of the few available staff at their rural branches.

5.1.5 Gender Preference by the RBIs in Benue State

Table 5 displays the variation in gender distribution of the agricultural loans by the RBIs in Benue State. The result indicated that all the RBIs had marked preference for the male gender. Of the 1263 successful applications, only 327 or $25.8 \%$ of them were women. Specifically, Bank of Agriculture had the highest percentage $(31 \%)$ of the women beneficiaries while the Microfinance bank had the least $(18 \%)$. The performance of the Bank of Agriculture in this result is not surprising because the bank is oriented to poverty alleviation. Second in the hierarchy, is the Deposit Money Bank where women accounted for $20 \%$ of the entire agricultural loan beneficiaries. This is followed by Microfinance banks which had $18 \%$ of the agricultural loan beneficiaries as women. Perhaps, the women's restricted mobility because of the need to cope with other family roles, and their relatively limited ability to offer collateral have therefore increased these RBIs indifference to them. 
Table 5: Number of Male and female Beneficiaries of Loans from RBIs

\begin{tabular}{|c|c|c|c|c|c|c|c|c|c|c|c|c|c|c|c|}
\hline & \multicolumn{5}{|c|}{ Deposit Money Banks } & \multicolumn{5}{|c|}{ Bank of Agriculture } & \multicolumn{5}{|c|}{ Microfinance Bank } \\
\hline & 2010 & 2011 & 2012 & Total & $\%$ & 2010 & 2011 & 2012 & Total & $\%$ & 2010 & 2011 & 2012 & Total & $\%$ \\
\hline Men & 48 & 75 & 68 & 191 & 79.58 & 181 & 176 & 153 & 510 & 69.58 & 72 & 75 & 88 & 235 & 81.03 \\
\hline Women & 17 & 17 & 15 & 49 & 20.42 & 64 & 71 & 88 & 223 & 31.42 & 10 & 15 & 30 & 55 & 18.97 \\
\hline Total & 65 & 92 & 83 & 240 & 100.00 & 245 & 247 & 241 & 733 & 100.00 & 67 & 72 & 97 & 290 & 100,00 \\
\hline
\end{tabular}

Source: Field Survey, 2012

\section{Conclusion And Recommendations}

Basically, the performance of these RBIs in financing agricultural production in Benue State is less than satisfactory especially when viewed from the point of their total loan commitment to agriculture as a percentage of their total savings mobilization in the rural areas. None of the RBIs under study committed at least 30 percent of the total funds mobilized in the rural areas to supporting rural industry and agriculture. It is however, believed that with time and policy changes, these RBIs will improve on their performance and grow to become major sources of credit to the small-scale rural farmers in Benue State and Nigeria in general. To achieve this however, increased financial resources should be made available by the State or Donor Agencies to these banks. These resources can contribute substantially in reactivating and re-energizing some of these RBIs especially during their negative cash flow stages. On the other hand, the RBIs should embark on aggressive mobilization of savings and recovering of their loan. This is because RBI success in mobilizing savings and recovering its debts are crucial to its becoming self-sustainable and having a better outreach. There is need to improve the logistics and infrastructures in the rural areas. This will engender high morale with the attendant increase in output and productivity. The rural roads should be made accessible all the year round to enhance and facilitate supervision of loans.

Finally, we recommend that the Central Bank of Nigeria should regulate these banks to support agricultural credit in the rural areas. For example before the deregulation of the economy, the rural banks were compelled to lend certain percentage of their deposits to the agricultural sector and failure to do so attracted penalty, but this has changed with deregulation. We are of the opinion that such policy should be revisited since these banks (rural branches of deposit money banks in particular) were making huge profit or doing well with the policy.

\section{Journal Papers:}

\section{References}

[1] Olatunbode, A.A. (1990). "Financing Nigerian Agriculture: Challenges of the 1990s. Journal of the Nigerian Agricultural and Cooperative Bank Ltd. 2(3): 80- 85.

[2] Odoemenem, I.U. (1992). Funding Agriculture through Cooperative. The case of Anambra

[3] State Village Adoption Scheme (ASVAS). Nigeria. Journal of International Agriculture, 31 (1) :. 25-35.

[4] Olashore. O. (1979) "Rural Banking; Strategies and Policies of Government and the Central Bank of Nigeria". Bullion. July, Pp. $48-54,110$

[5] Vogel, R.C. (1981). "Rural Financial Market Performance. Implications of Low Delinquency Rate." American J. of Agric Econs. Vol. 63 No. 1, Pp 58-72.

Books:

[6] Mokinnon.R. (1973). Money and Capital in Economic Development. The Brookings Institution Washington. D.C. 248 Pp.

[7] Ojo. A.T. and Adewunmi W. (1982). Banking and Finance in Nigeria. Graham Burn, Bedfordshire. P. 277.

[8] Anyanwu, J.C, Oaikhenan H., Oyefusi A., Dimowo F.A (1997). The Structure of the Nigerian Economy (1960-1997). ( $\left(1^{\text {st }}\right.$ Edition). Joanee Educational Publishers Ltd. Awka, Nigeria. Pp. 169-170.

\section{Chapters in Books:}

[9] Barau, A.D. (1991). "Resource Poor Farmers in Nigerian Agriculture: How not to help

[10] them". In :(Olukosi, J.O. Ogungbile; and B.A. Kalu (eds). A Publication of the Nigerian National Farming Systems Research Network. Pp. 6.

[11] Yaron. J. (2000). "From Directed Credit to Rural Financial Intermediation: The Revised

[12] Role of the Government: in: J. Ruotsi (ed). After the Reforms: which Way Forward for Central Banks in Rural Finance. Africa Rural Finance Series Vol. 1, Published by African Rural and Agricultural Credit Association, Nairobi, Kenya. Pp 1-20.

\section{Proceedings Papers:}

[13] Edordu. C.C. (1986). "The Role of Central Bank of Nigeria in Funding Agricultural Development in Nigeria." A paper presented at a Seminar on Financing Agricultural Development in Nigeria Organized by ARMTI, Ilorin, Nigeria. 22pp.

[14] Nnanna O.J. (2001), "Bank Lending Behaviour and Output Growth: An Empirical Analysis with Implication on Monetary Policy in Nigeria". CBN Economic and Financial Review, 40(3).

[15] Nnanna. O.J. (2005). "Beyond Bank Consolidation: The Impact on Society" in CBN $4^{\text {th }}$ Monetary Policy Conference. PP 45.

[16] Nkposong O.E. (1999). "Small Scale Farmers" Poverty Level, Implications for Formal Agricultural Credit Sourcing Fabiyi, Y.L. and E.O. Idowu (Eds) Poverty Alleviation and Food Security in Nigeria. Ibadan. Nigeria Association of Agricultural Economists (N.A.A.E.) PP 10-12.

[17] Yaron J. (1992). "Sustainability Criteria in RFIs". The World Bank Economic Review 6:250-60.

[18] Yaron. J; M. Benjamin and G. Piprek (1997). "Rural Finance Issues, Design and Best Practices. No. 14, Environmentally and Socially Sustainable Development Studies and Monograph Series. Washington D.C.; World Bank, 120pp. 
[19] Yaron, J. (1994). "Successful Rural Financial Institutions" The World Bank Research Observer. A quarterly Publication of the International Monetary Fund and the World Bank, 9( 1):220-240 Jan. 1994.

[20] Gurgand, M;G. Pederson; and J. Yaron, (1994). "Outreach and Sustainability of Six Rural Finance Institutions in Sub-Saharan Africa." World Bank Discussion Papers. 248 pp.

[21] National Population Commission. (2006). Populatin Census Statistics. Abuja, Nigeria. Pp. 1-5.

[22] BNARDA. (1999). Benue State Agricultural and Rural Development Authority. Annual Report, 51pp.

APPENDIX 1

SAMPLE SELECTION (SAMPLING PROPORTION 10\%)

\begin{tabular}{|c|c|c|c|c|}
\hline Zones & LGAs & Communities & $\begin{array}{l}\text { Loan Beneficiaries } \\
\text { Population }\end{array}$ & Sample Size \\
\hline \multirow[t]{6}{*}{ Zone A } & Ukum & Kyado & 110 & 11 \\
\hline & & Gbeji & 101 & 10 \\
\hline & Katsina-Ala & Abaji & 102 & 10 \\
\hline & & Gbor & 80 & 8 \\
\hline & Vandeikya & Tsar & 71 & 7 \\
\hline & & Ihugh & 90 & 9 \\
\hline \multirow[t]{6}{*}{ Zone B } & Gboko & Yandev & 149 & 15 \\
\hline & & Ipav & 180 & 18 \\
\hline & Gwer & Taraku & 142 & 14 \\
\hline & & Ikpayongo & 118 & 12 \\
\hline & Makurdi & Tatyough & 79 & 8 \\
\hline & & Apir & 109 & 11 \\
\hline \multirow[t]{6}{*}{ Zone C } & Otukpo & Ugboju & 81 & 8 \\
\hline & & Otukpicho & 59 & 6 \\
\hline & Okpokuu & Ugbokolo & 120 & 12 \\
\hline & & Ichama & 83 & 8 \\
\hline & Oju & Amaka & 28 & 3 \\
\hline & & Ohuohuo & 102 & 10 \\
\hline Total & & & 1804 & 180 \\
\hline
\end{tabular}

Source: Field Survey, 2012 